\title{
PROBLEMS AND PILLARS OF BUSINESS EDUCATION IN KAZAKHSTAN
}

\author{
Daniya Asanova., PhD, assistant professor \\ Kazakhstan, Almaty, Almaty Management University \\ Doctoral student of the DBA program
}

DOI: https://doi.org/10.31435/rsglobal_ws/30082018/6055

\section{ARTICLE INFO}

Received: 17 July 2018

Accepted: 22 August 2018

Published: 30 August 2018

\section{KEYWORDS}

management, business education.

\begin{abstract}
The beginning of development of Kazakhstani business education dates back to the end of the $80 \mathrm{~s}$ - beginning of the 90 s of the XX century. Along with the achievements in the sphere of business education, there are key issues that hampers the development of business schools and have an impact on the learning outcomes and the quality of business education in general. This article reviews the stages of development of business education in Kazakhstan and explores key issues in this sphere. Furthermore, the author suggests a series of systematic measures to strengthen the capacity of business education in Kazakhstan and gives the examples of contribution of Almaty Management University in this sphere.
\end{abstract}

Citation: Daniya Asanova. (2018) Problems And Pillars Of Business Education In Kazakhstan. World Science. 8(36), Vol.1. doi: 10.31435/rsglobal_ws/30082018/6055

Copyright: (C) 2018 Daniya Asanova. This is an open-access article distributed under the terms of the Creative Commons Attribution License (CC BY). The use, distribution or reproduction in other forums is permitted, provided the original author(s) or licensor are credited and that the original publication in this journal is cited, in accordance with accepted academic practice. No use, distribution or reproduction is permitted which does not comply with these terms.

Introduction. In the epoch of globalization, business education is consider the key driver of the stable economy development, because precisely it prepares entrepreneurs, new managers, leaders, from which depends economic success of the country.

Research results. Business education of Kazakhstan has its own features. It went over particular stages in its development. The business education in Kazakhstan has originated in the end of the 80 s - beginning of the 90 s of the XX century

The first stage is the stage of genesis $(1985$ - 1995) - there was a separation of the business education from the professional economic education. This was due the obtaining state independence. Exactly in these years, the first business schools have been opened (Almaty School of Managers, which subsequently transformed to Alma University and KIMEP).

The second stage is the stage of the growth $(1996$ - 2006). There was a rapid growth of business education providers. In this period a big amount of private universities (more than 100) and training companies appeared. 


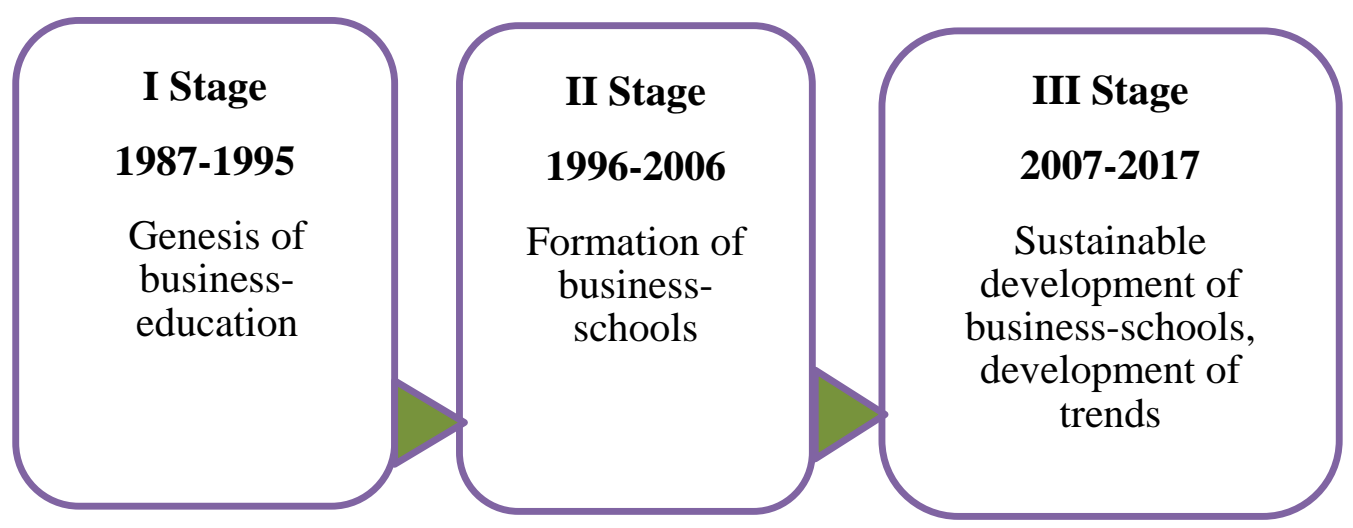

Fig. 1. Stages of business education development in Kazakhstan (compiled by the author)

The third stage - the stage of dynamic qualitative growth (2007-2017). It is a period of systematic development of business education. Politics focused more on the increase of the quality of educational services. In this period, the state introduced politics of optimization of the number of universities, The State program of education development of the Republic of Kazakhstan for 20162019 began its implementation, and state expenses on private business education were increased. Private universities started obtaining state grants.

At this stage, Kazakhstan business education began to integrate in the international educational space: academic mobility has grown, double-degree MBA programs have been launch, and private business schools became participants of "Bolashak State International Scholarship". Business schools recently started to set real partnerships with the employers, businesses, started projects with the National Chamber of entrepreneurs, which is the good sign. Business schools have been actively involved in implementation the State program of industrial-innovative development of Kazakhstan (SPIID), with extrapolation on the issues of providing specialists.

The system of business education of Kazakhstan represented by (1) business schools, (2) training and consulting companies ("The Big Four"), (3) training centers and corporate universities in companies, and (4) representatives of foreign business schools and training companies in Kazakhstan.

Together with universities/business schools, market of business education is broadly represent with training and consulting companies ("The Big four"), who focus on short-term programs, consulting projects, business courses, seminars and trainings. Big role in education of entrepreneurship personnel goes to Entrepreneurship Development Fund "Damu". Besides native universities and training companies, there are representations of the foreign business schools and companies on the market of business education of Kazakhstan, which offer short-term business courses and seminars. Annually international fairs of MBA (QS World MBA Tour, Access MBA and others) take place in Kazakhstan. The participants of these fares are serious competitors of the native business universities.

An extensive contribution in development of business education of Kazakhstan is make by international organizations. Hundreds of entrepreneurs, top and middle level managers of Kazakhstan companies pass the education foreign internships in the leading foreign companies abroad, with the help of grants from international organizations.

Thus, the market of business education was formed, and today it is in the stage of progressive development.

Among the most famous Kazakhstan business schools are the following: Alma University, KIMEP, University of International Business (UIB), International Business School of the New Economic University named after T. Ryskulov. In 2012, the Graduate school of business of Nazarbayev University has been opened in Astana city, which is supposed to become Business School of the international level in accordance with international standards. Among the most popular programs at these business schools, are Master of Business Administration (MBA), Doctor of Business Administration (DBA), and programs of professional development (executive education). Double-degree international programs are very popular, for example, Alma University's joint programs with HEC (France), MSM (the Netherlands), RANEPA - Russian Academy of National Economy and Public Administration (Russia).

Today, Kazakhstan as the dynamic society provides all conditions for development of business education. There are some evidences, for example 
- according to 2017 World Economic Forum report Kazakhstan is on the 32nd in Global index of competitiveness among 63 countries [1];

- according to 2017 annual survey by World Bank on the 36st in Doing Business ranking among 190 countries [2];

- according to Doing Business ranking 2017 Kazakhstan is the 1st among 190 countries in the rating on the indicator "Protection of minority investors". The second year the republic is included in the first ten countries on the indicator "Contract execution" (6th place). According to the indicator, "Registration of property" the country took 17th position.

In accordance with the World Economic Forum report for global competitiveness in the category of "Quality of business schools" [3]:

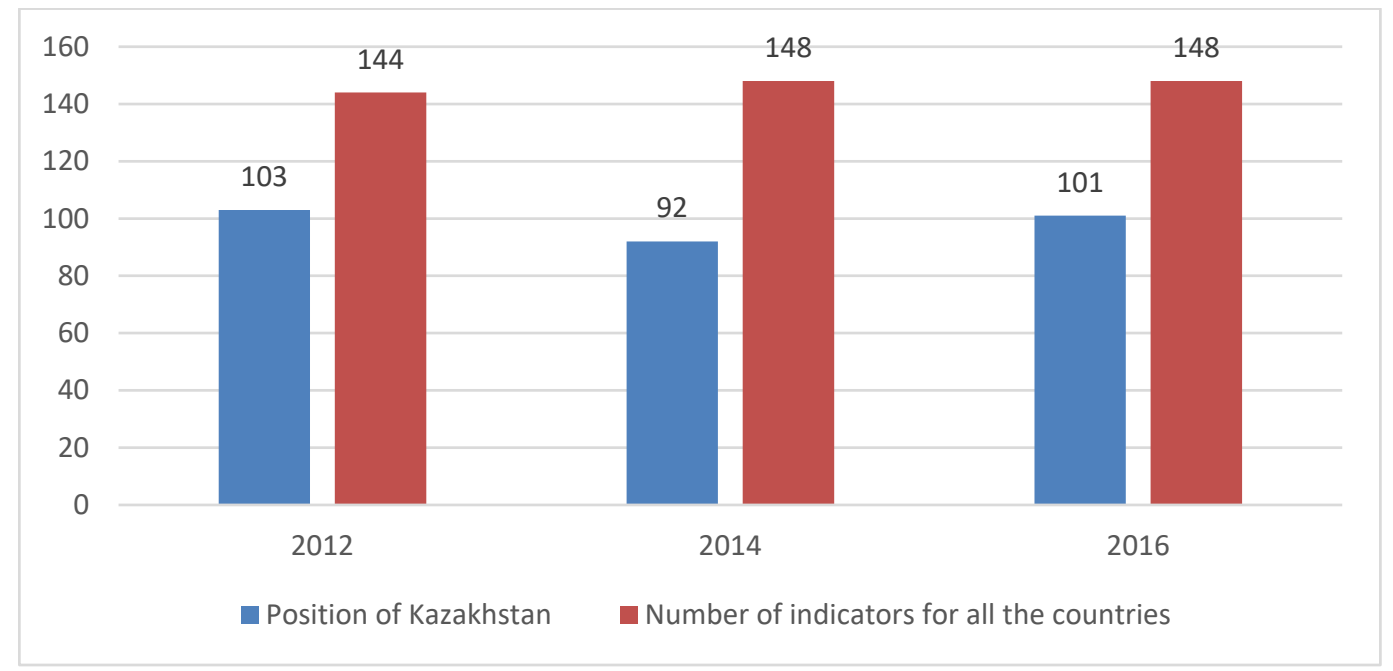

Fig. 2. Present: Kazakhstan in the ranking of countries in terms of "The quality of business schools". Source: WEF Data, Reports on global competitiveness of 2012-2016

However, there are number of key issues that exist along with the achievements in the sphere of business education.

First. The gap between education and the business. Existing communication of business schools with the real economy and businesses is fragmented; there is no systematic approach to joint work, resulting in a gap between the students' level, particularly undergraduate students and the requirements of the labor market.

The results of the survey of employers showed that, in general, employers are aware of the importance and the need for close collaboration with universities and business schools, because they are interested in high quality training to meet modern market demands. Among the main reasons for the existing gap and the lack of systematic work with the universities, as the majority of respondents identify, is the lack of motivation, both tangible and intangible. In this regard, professional associations, employers, companies, universities and business schools should develop mechanisms of social relationship and partnership to ensure the proper motivation of all stakeholders in this cooperation.

Second. The quality of curricula and programs of business schools need special attention, with the emphasis on learning outcomes and managerial competences of the graduates. Case studies of Kazakh companies are not widely used in the programs in business schools. The first textbook on case studies of Kazakh companies is to be publish at Alma University. There are not enough Kazakhstan authors on management, marketing, finance etc. in Kazakhstan. There are practically no textbooks and curricula for Master, MBA and doctoral studies in Kazakh. In addition, there is an insufficient number of modern business literature translated from English into Russian and Kazakh languages.

Unfortunately, nowadays, there are significant gaps in the development of so-called soft skills, i.e., personal competencies such as communication skills, leadership skills, and ability to work in a team. It makes sense for the heads of business schools to review the curricula and syllabus of courses on the subject of strengthening the development of personal competencies.

Such items as non-uniformity of offers and services in the field of post-graduate business education in the regions of Kazakhstan should be note concerning regional development. 80\% of business 
schools and training / consulting firms are concentrated in two biggest city in Kazakhstan - Almaty and Astana. There are representations of several business schools in cities such as Atyrau, Aktobe, Shymkent and Pavlodar, as well as branches of training companies that offer short-term courses and public seminars. There is a great necessity for programs in Kazakh in other regions of Kazakhstan.

A major problem of Kazakhstan's business schools is the lack of qualified practitioners among faculty. The teachers of economic disciplines often lack practical experience in the workplace, i.e., they are not familiar with inside problems, therefore, possess only theoretic knowledge. Practitioners, i.e. experts with successful experience, do not know teaching methods. Given the high requirements for MBA and DBA programs from the students, most of whom are senior and middle managers, business schools have to attract business coaches. The number of business coaches in Kazakhstan, unfortunately is not enough to cover the demand. That is why there are the same faculty as business trainers and authors of their own courses.

Another disadvantage of the Kazakhstan business schools to be noted is the low MBA entry requirements (no entrance exams like GMAT, which is used by Western business schools). As the result, strong students who possess all the necessary basic knowledge and skills for MBA programmes can sit together with weak students who have no previous relevant education and are not aware of basics of economics and management. Therefore, business schools need to strengthen the requirements for admission and acceptance of candidates for the business education programs.

MBA programs market is growing very unevenly, so there was a rapid growth in 2005-2007, and there was reduction in the number of students during the crisis in 2008-2010. Afterwards there was a slight recovery of the market in 2011-2013, followed by decline in 2014-2015, and at present, the number of those who wish to study has stabilized.

There are almost no full-time MBA programs now, existing programs are part-time mainly. In addition, Kazakhstan business schools are not well integrate into the international educational community. Not all business schools have international accreditations or rankings such as AMBA or Eduniversal. In fact, the existing problems in the field of business education hamper the development of business schools and have an impact on the learning outcomes and the quality of business education in general.

Conclusions. In order to strengthen the capacity of business education Kazakhstan, a series of systematic measures should be implement:

First, it is advice to strengthen the integration of education, science and industry.

The "Triple Helix" [4] or the integration of university, business and government becomes a decisive factor in the development and growth of competitiveness of the national economy. According to the international forms of collaboration, like American and Asian models, integration of science, education and production is the main mechanism of innovative development of country.

Secondly, it is reasonable to enhance the contribution of business education into the industrial and innovative development of the country.

Thirdly, it is necessary to work more intensively with the National Chamber of Entrepreneurs of Kazakhstan.

Fourthly, it is necessary to find new forms of organization and management of modern business school. The most interesting is the way of transformation of universities in the organization of a new type - business organizations focused on meeting the needs of the market.

The meaning of the entrepreneurial university is to create new high-tech production with involvement of faculty and students into practical and consulting activities.

Fifth, it is advisable to carry out serious research in the field of business education in Kazakhstan.

\section{REFERENCES}

1. The Global Competitiveness Report 2017-2018: World Economic Forum. Geneva, 2017 (https://www.weforum.org/reports/the-global-competitiveness-report-2017-2018).

2. Doing Business 2017: Equal Opportunity for all, a World Bank Group flagship publication (http://www.doingbusiness.org/reports/global-reports/doing-business-2017).

3. The Global Competitiveness Report 2015-2016. World Economic Forum. Geneva, 2015.

4. Etzkowitz H. The Triple Helix: University-Industry-Government in action. Routledge, London. 2008. 157p. 